J. Range Manage.

48:240-245 May 1995

\title{
Growth of winterfat following defoliation in Northern Mixed Prairie of Saskatchewan
}

\author{
JAMES T. ROMO, ROBERT E. REDMANN, BRENDAN L. KOWALENKO AND ANDREW R. \\ NICHOLSON
}

Authors are Assaciate Professor, Professor, Graduate Research Assistant and former student, Dep. of Crop Science and Plant Ecology, Univ. of Saskatchewan, 51 Campus Drive Saskatoon, Sask,, S7N SAS, Canada.

\begin{abstract}
An observed increase in winterfat (Ceratoides lanata (Pursh) J.T. Howell) on ungrazed rangeland suggests that this shrub may potentially be an important forage resource in the Northern Mixed Prairie under improved grazing management. The objectives of this study were to: 1 ) compare density, frequency, and cover of winterfat in a grazed pasture and site that had been protected from grazing for about 30 years; and 2) evaluate regrowth of winterfat following defoliation during the growing season on a clayey range site in Saskatchewan. Density, frequency, canopy cover, and basal cover were significantly greater in the protected range than the grazed pasture. Density $\left(1.1 \mathrm{SE} \pm 0.01\right.$ plants $\left.\mathrm{m}^{-2}\right)$ and frequency (70\% SE \pm 3.6 ) were about 2 -fold greater, while canopy cover (7.0\% SE \pm 1.4$)$ and basal cover $(1.7 \% \mathrm{SE} \pm 1.5)$ were 7 - to 8-fold greater, in the protected versus grazed range. When defoliated to a 5-cm stubble in May, June, or July plants produced significant amounts of regrowth but not when herbage was removed in August. When defoliated in late July or August current year production the following year was significantly lower than control and earlier defoliations. Current year production peaked in late July and August. Total standing crop was 2- to 4fold greater in the control than the defoliation treatments because the biomass produced in previous years was removed from clipped plants. Because winterfat produces substantial amounts of new growth following defoliation in May, June, or July it is recommended that this shrub be grazed only once during the growing season to prevent grazing of this regrowth. Plants defoliated in May can potentially produce biomass equal
\end{abstract}

Research was funded by Saskatchewan Agriculture Development Fund Research Grant R-89-05-0.91 to JTR and by the Dep. of Crop Science and Plant Ecology, University of Saskatchewan. Portions of this research were submitted to the Dep. of Crop Science and Plant Ecology by BLK and ARN in partial fulfillment of the requirements for the Honors Program in Plant Ecology, and the Bachelor of Science of Agriculture Degree at the Univ. of Saskatchewan.

We thank B. Pylypee for coordinating some of the field sampling, assisted by several undergraduate students. The 1986 defoluation experiment was set up by Yueshu Li. Appreciation is also extended to Daryl Nazar, Dandan Xiang. Renny Grilz, Katie Andrews, Lester Pryce. Christy Kowalenko. Kim Trulicz and Sharlene Weese for their assistance in the field and laboratory. We also thank 2 anonymous reviewers for constructive comments on an eurler draft.

Manuscript accepted 20 Sept. 1994. to control the following year whereas plants defoliated in June, July, or August will likely require more than 1 year of rest to recover their annual productivity.

Key Words: Ceratoides lanata (Pursh) J.T. Howell, defoliation, grazing management, productivity, standing crop

The Northern Mixed Prairie in Canada is generally described as being dominated by perennial grasses and forbs (Clarke et al. 1943 . Coupland 1950, 1961) with shrubs viewed as minor components. As a result of this perception, and because grasses generally produce more biomass than shrubs, most decisions in grazing management are based on grasses. Winterfat (Ceratoides lanata (Pursh) J.T. Howell) is readily grazed by livestock and declines under grazing (Smoliak 1965). Clarke and Tisdale $(1936,1945)$ and Smoliak and Bezeau (1967) recognized the superior forage quality of this shrub and its decline under improper grazing management on the Canadian Prairies where it is most abundant in the Agropyron-Koeleria and Bouteloua-Agropyron faciations (Coupland 1950).

Although winterfat has been the subject of intensive study elsewhere (e.g. Coyne and Cook 1970, Cook and Child 1971, Moore et al. 1972, Fernandez and Caldwell 1975) it has received limited attention in the Northern Mixed Prairie. At the Matador Research Station in southern Saskatchewan, winterfat has increased dramatically since the Station was established as an International Biological Program research site in 1967 (R.E. Redmann pers. obs.). Since 1963 the Research Station has been protected from livestock grazing. The observed increase in winterfat suggests that it may potentially be more abundant in the Northern Mixed Prairie than previously recognized, and that through improved grazing management it may become a more important constituent of this rangeland.

The studies reported here were initiated to: 1) compare density, frequency and ground cover of winterfat in a grazed and protected range; and 2) determine the growth and productivity of winterfat following a single defoliation event on various dates throughout the growing season. This information will assist in developing grazing management strategies for maintaining or improving the productivity of winterfat on Northern Mixed Prairie. 


\section{Materials and Methods}

\section{Study Site and Experimental Design}

Research was conducted at the 778 ha-Matador Research Station $\left(50^{\circ} 42^{\prime} \mathrm{N}, 107^{\circ} 43^{\prime} \mathrm{W}\right.$, elev. $\left.685 \mathrm{~m}\right)$ approximately $40 \mathrm{~km}$ southeast of Kyle and $70 \mathrm{~km}$ north of Swift Current, Saskatchewan. The area is a clayey range site (Abouguendia 1990) and soils are Rego Brown and Culcareous Brown Series in the Sceptre Association of the Chernozemic Brown Subgroup (Aridic Borolls) (Coupland et al. 1974). This grassland is classified as the Agropyron-Koeleria Faciation of Mixed Prairie (Coupland 1950 ). Annual temperatures average $3.3^{\circ} \mathrm{C}$ with January the coldest month at $-1+.5^{\circ} \mathrm{C}$ and July the warmest, averaging $18.8^{\circ} \mathrm{C}$. Annual precipitation averages $327 \mathrm{~mm}$ with approximately two-thirds being received as rain during the summer.

Density and cover for winterfat were compared on the Matador Research Station and the adjacent 2.203-ha pasture that is grazed by cattle annually in May and June and again in September and mid-October, or is continuously grazed from May through midOctober. Zhang and Romo (1994) estimated that the ecological condition of the pasture was fair. Soils of the pasture are the same as those of the Research Station. In 1987, 4-100-m transects were established and at 25 randomly selected points on each transect the density and frequency of winterfat were determined in a circular $1 \mathrm{~m}^{2}$ quadrat. In 1987,1989, 1990 and 1991, 2 transects were randomly placed in the Research Station and pasture about $50 \mathrm{~m}$ from the fence that separates the 2 sites. Canopy cover of winterfat was estimated on the transects using line intercept (Kinsinger et al. 1960). Basal cover of winterfat was estimated with point intercept (Coupland 1950) in 1991, 1992, and 1993 in each of 4 transects.

The defoliation studies were conducted on the Matador Research Station with the first study in 1986 and 1987 in a randomized-complete-block design with 3 replicates of plots that were $3 \times 3 \mathrm{~m}$. On 15 June or 15 July 1986 these plots were defoliated with a Jari mower to a stubble height of about $5 \mathrm{~cm}$ and winterfat was collected from the entire plot. Even though the shortcomings of elipping studies were discussed by Caldwell (1984) this intensity of defoliation was similar to that which winterfat plants experienced in the adjacent range that is grazed by cattle (J.T. Romo pers. obs.). These samples were dried at $80^{\circ} \mathrm{C}$ and separated into woody growth and production of the current year. On 10 August 1987 these same plots, and a control that had not been defoliated, were revisited and all winterfat plants were clipped at ground level to determine regrowth. This plant material was dried and separated as above.

The second study conducted was expanded to examine the effects of 9 different dates of defoliation on the regrowth of individual plants. A randomized-complete-block design with 10 replicates of $5 \times 10 \mathrm{~m}$ plots was used with separate blocks established in 1990, 1991, and 1992. Separate blocks were established because we were interested in the effects of a single defoliation event on winterfat. Plots were mowed only once with a Jari mower to a stubble height of about $5 \mathrm{~cm}$ and all the cut material was removed. The first date of defoliation was in early May and additional plots were defoliated at approximately 2 -week intervals until late August in each year. On 12 September 1991 and 26 September 1992 biomass was determined for individual plants that were defoliated the current year by randomly locating and clipping 1 plant per replicate at ground level. The year after imposing the defoliation treatment, growth was determined at about 2-week intervals from May or June through August by clipping at ground level 1 randomly selected plant per replicate; plants were never re-clipped. All samples were oven dried at least 48 hours at $80^{\circ} \mathrm{C}$. separated into shoots and leaves of the current year, and woody material, and then weighed.

Means and their standard errors for density, frequency and cover were calculated and used for comparisons between the Research Station and the pasture. Data of the first defoliation study were analyzed with analysis of variance in randomizedcomplete-block design with 3 replicates and 2 defoliation dates. In the second study, standing crop produced in the current year and total standing crop were analyzed within years with a splitplot analysis of variance in a randomized-complete-block design with 10 replicates (Petersen 1985). Dates of defoliation were the main plots and dates of sampling were subplots. Means among defoliation treatments were separated with Fisher's protected LSD (Petersen 1985). Data of regrowth in the year of defoliation were analyzed with analysis of variance, and best-fit polynomial regression equations for standing crop versus date of defoliation were developed (Petersen 1985). Statistical significance was assumed at $P \leq 0.05$.

\section{Results and Discussion}

\section{Climatic Conditions}

Precipitation totaled $496 \mathrm{~mm}$ in 1990-91, the wettest year, and $315 \mathrm{~mm}$ in the driest year of 1991-92 (Table 1). Of the total precipitation from Septenber through March contributed $15 \%$ in $1990-91$ to $38 \%$ in $1986-87$ while averaging about $30 \%$ in the

Table 1. Precipitation received during the winterfat defoliation studies. Data are for Beechy, Saskatchewan about $\mathbf{4 0} \mathrm{hm}$ northeast of the study site.

\begin{tabular}{|c|c|c|c|c|c|c|c|}
\hline \multirow[t]{2}{*}{ Year } & \multicolumn{7}{|c|}{ Month } \\
\hline & Sep. - Mar. & Apr. & May & Jun. & Jul. & Altg. & Total \\
\hline \multicolumn{8}{|c|}{ 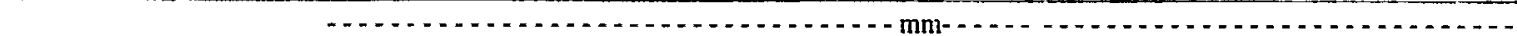 } \\
\hline $1985-86$ & 96 & 6 & 72 & 41 & 96 & 29 & 340 \\
\hline $1986-87$ & 164 & 12 & 39 & 37 & 112 & 59 & 423 \\
\hline $1989-90$ & 132 & 19 & 43 & 77 & 120 & 27 & 418 \\
\hline $1990-91$ & 72 & 59 & 65 & 224 & 40 & 36 & 496 \\
\hline $1991-92$ & 94 & 8 & 48 & 33 & 80 & 52 & 315 \\
\hline 1992.93 & 145 & 20 & 15 & 50 & 69 & 124 & 423 \\
\hline \multicolumn{8}{|l|}{ Long-term } \\
\hline mean (1961-90) & 115 & 16 & 40 & 63 & 60 & 34 & 327 \\
\hline
\end{tabular}


other years. July was the wettest month in all years except 1991 when June received the most precipitation. Except in 199I and 1993 when August and June received the least precipitation, respectively, April was the driest month.

\section{Density, Frequency and Cover for Winterfat}

Density, frequency, and cover were significantly greater in the Research Station than the pasture. Density of winterfat averaged 1.1 plants $\mathrm{m}^{-2}(\mathrm{SE} \pm 0.01)$ in the Research Station. The 0.5 plants $\mathrm{m}^{2}$ (SE \pm 0.13 ) in the grazed pasture is closer to the $0.0-0.4$ plants $\mathrm{m}^{2}$ reported for this region by Coupland (1950). In southeastern Alberta density of winterfat increased $68 \%$ over a 10 year period when grazing was removed (Clarke et al. 1943). Frequency averaged $70 \%(\mathrm{SE} \pm 3.6)$ and $39 \%(\mathrm{SE} \pm 9.2)$ in the protected and grazed area, respectively. This frequency is considerably higher than the $0-24 \%$ reported by Coupland (1950). Canopy cover averaged $7.0 \%(S E \pm 1.4)$ in the Research Station and $0.8 \%$ $(S E \pm 0.3)$ in the grazed pasture. Basal cover averaged $1.7 \%$ $(S E \pm 1.5)$ in the Research Station and $0.2 \%(S E \pm 0.2)$ on the grazed range. When working in the same area as the present study, in the 1940 's, Coupland (1950) reported that winterfat had a basal cover of $0.04 \%$. In southern Alberta basal area for winterfat ranged from 0.06 to $0.81 \%$ depending on the grazing history (Smoliak 1965).

\section{Growth of Plants Defoliated in 1986}

In August 1987 current year production $\left(7.2 \mathrm{~g} \mathrm{~m}^{-2} \mathrm{SE} \pm 1.1\right)$ and total biomass $\left(16.2 \mathrm{~g} \mathrm{~m}^{-2} \mathrm{SE} \pm 2.5\right.$ ) were not significantly different after defoliation on 15 June or 15 July 1986. In August 1987 , when biomass was redetermined, that of the current year $(6.3 \mathrm{~g}$ $\left.\mathrm{m}^{-2} \mathrm{SE} \pm 1.5\right)$ and total $\left(16.5 \mathrm{~g} \mathrm{~m}^{-2} \mathrm{SE} \pm 3.4\right)$ were statistically similar among the control and defoliation treatments. This total standing crop was nearly 7 -fold greater than the $2.5 \mathrm{~g} \mathrm{~m}^{-2}$ produced by winterfat in southeastern Alberta (Clarke et al. 1943).

\section{Growth Following Defoliation in 1991 and 1992}

Regrowth decreased as the date of defoliation was delayed (Fig. 1). Growth in 1991, the wettest year, was greater than in 1992, the driest year of study. Current year growth was essentially nil when plants were defoliated in August 1991 or in late July or August 1992. Reduced regrowth after the early May versus late May defoliations was observed in 1991. but not in the drier

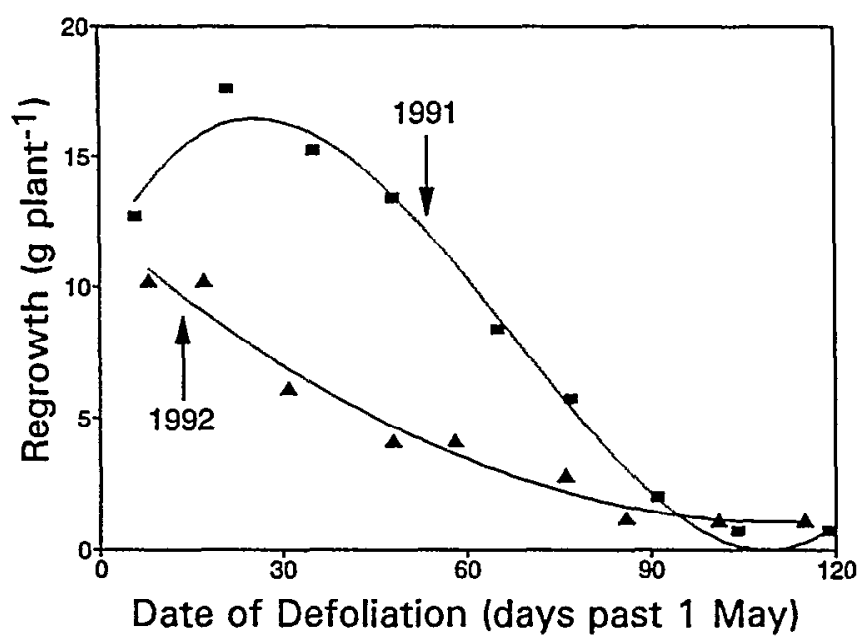

Fig. 1. Regrowth of winterfat harvested on 12 Sept. 1991 and 26 Sept. 1992 following defoliation on 9 dates in 1991 or 1992. Lines are from fitted regression equations and each symbol is the mean of 10 replicates.

year of 1992. Cook and Child (1971) also reported that vigor of winterfat was severely reduced by defoliation in May. Because winterfat was initiating its growth when defoliated in May, its carbohydrate reserves were likely near their seasonal low (Coyne and Cook 1973) and plants relied on current photosynthate for regrowth (Caldwell 1984). Alternatively meristematic and photosynthetic limitations (Wandera et al. 1992, Bilbrough and Richards 1993) may have limited regrowth in 1991, whereas in 1992 environmental conditions (Richards and Caldwell 1985) may have placed greater restrictions on carbon gain and growth.

\section{Production of Plants Defoliated in 1990}

In 1991 the current year production for plants was affected by the date of defoliation $x$ date of sampling interaction (Table 2 ). Control plants had the most production, and plants defoliated in July or August the least. Depending on the date of defoliation, peak production was observed in mid-July to August.

Date of defoliation and date of sampling independently affected

Table 2. Current year production for winterfat defoliated in 1990 and sampled in 1991.

\begin{tabular}{|c|c|c|c|c|c|c|c|c|c|}
\hline \multicolumn{10}{|c|}{ Sampling Date in 1991} \\
\hline \multirow{2}{*}{$\begin{array}{l}\text { Date of } \\
\text { defoliation }\end{array}$} & \multirow{2}{*}{$\begin{array}{c}-11 a y=- \\
22\end{array}$} & \multicolumn{2}{|c|}{$\ldots . .$. Jun.. $\ldots$} & \multicolumn{3}{|c|}{ 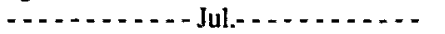 } & \multicolumn{3}{|c|}{$\ldots-\ldots$ Aug. $\ldots$} \\
\hline & & 4 & 17 & 4 & 16 & 30 & 13 & 27 & Mean \\
\hline & $\ldots$ & $\ldots \ldots$ & $\cdots$ & $\ldots . .$. & plant & 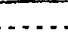 & $=\ldots$ & $\cdots$ & $\ldots$ \\
\hline Control & $5.0^{\mathrm{I}}$ & 54 & 9.3 & 12.6 & 8.3 & 10.3 & 26.3 & 16.2 & 11.7 \\
\hline 9 May 1990 & 2.0 & 5.1 & 6.3 & 9.1 & 11.3 & 10.7 & 10.8 & 9.5 & 8.1 \\
\hline 22 May 1990 & 3.2 & 3.9 & 9.7 & 9.1 & 7.3 & 13.4 & 8.5 & 15.9 & 8.9 \\
\hline 5 Jun. 1990 & 3.6 & 7.1 & 7.2 & 6.5 & 10.2 & 6,0 & 12.4 & 10.8 & 8.0 \\
\hline 20 Jun. 1990 & 3.3 & 5.4 & 5.5 & 7.8 & 4.3 & 12.1 & 9.7 & 8.9 & 7.1 \\
\hline 9 Jul. 1990 & 2.2 & 5.8 & 4.5 & 7.5 & 4.6 & 8.7 & 5.5 & 7.2 & 5.8 \\
\hline 19 Jul. 1990 & 2.4 & 4.0 & 4.6 & 6.8 & 6.0 & 8.9 & 6.0 & 11.6 & 6.3 \\
\hline 31 Jul. 1990 & 1.5 & 24 & 5.1 & 4.3 & 8.0 & 9.2 & 8.4 & 7.6 & 5.8 \\
\hline 14 Aug. 1990 & 1,9 & 3.1 & 4.2 & 6.0 & 3.2 & 3.1 & 9.2 & 7.7 & 4.8 \\
\hline 28 Aug. 1990 & 1.3 & 2.7 & 4.3 & 6.6 & 7.1 & 10.5 & 9.2 & 12.7 & 6.8 \\
\hline Mcan & 2.6 & 4.5 & 6.1 & 7.6 & 7.0 & 9.3 & 10.6 & 10.8 & 7.3 \\
\hline
\end{tabular}

I Standard error for sampling date $\times$ date of defolatron interaction is 2.0 . 


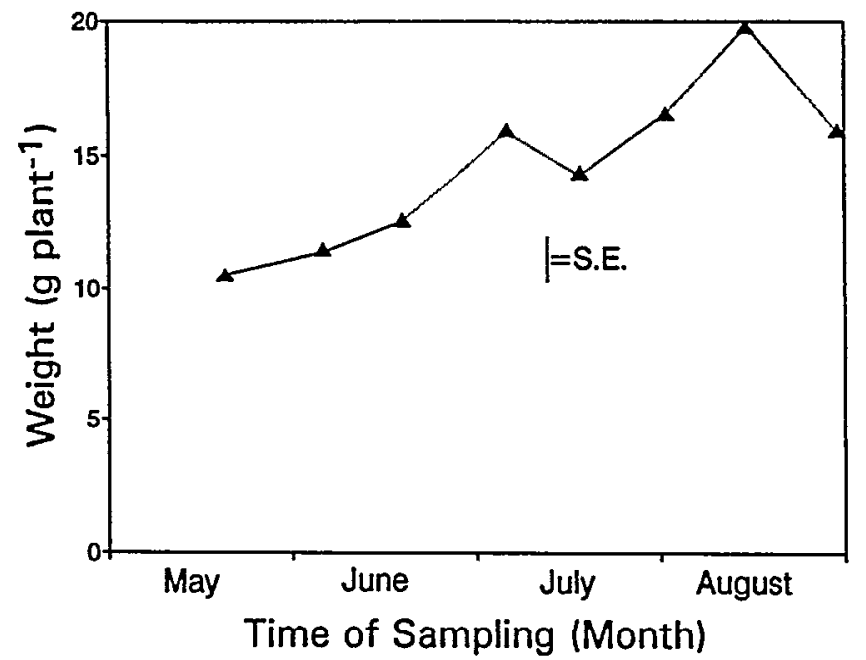

Fig. 2. Total biomass averaged across control and defoliation treatments for winterfat defoliated in 1990 and sampled in 1991. S.E. is standard error for the means.

total biomass. Total biomass of plants in the control was about 2to 4-fold greater than those that had been defoliated (Table 3). Plants that were defoliated on 14 August 1990 were smallest among those in the defoliation treatments. The seasonal pattern of growth was similar among treatments, peaking in August (Fig. 2).

\section{Growth of Plants Defoliated in 1991}

Current year production and total biomass in 1992 were affected by the date of defoliation and date of biomass sampling. Current year production peaked in late July while total biomass was greatest in late June to early July (Fig. 3). Current year production was not significantly different among plants in control and those defoliated in May to mid-July (Table 4). Plants that were defoliated in August produced the least biomass. Production of the current year was significantly correlated $(\mathrm{r}=0.87, P \leq 0.05)$ with regrowth in 1991, suggesting that the plants which regrew more biomass in the year of defoliation also produced more the next year.

Total biomass was about 2- to 4-fold greater in the control than plants that had been defoliated (Table 4). Among the defoliation treatments, total biomass tended to be greatest when herbage was removed in May or June and least in August, respectively. Total biomass was greater because plants defoliated earlier had more biomass production in 1991 and this biomass was classified as woody material in 1992 .

\section{Growth of Plants Defoliated in 1992}

In 1993 current year growth and total biomass were not significantly different among treatments on dates of sampling (Fig. 4). Biomass in both categories was greatest in August.

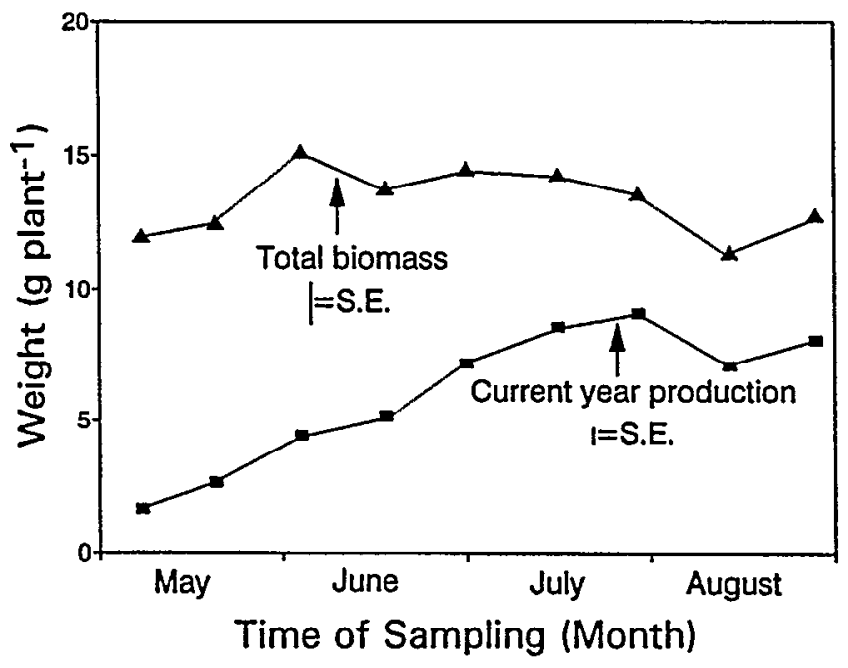

Fig. 3. Total biomass and current year production averaged across control and defoliation treatments for winterfat defoliated in 1991 and sampled in 1992. S.E. is standard error for the means.

Current year production was significantly different among treatments with plants defoliated in early May producing most and control was intermediate in its production (Table 5). When defoliated in mid-May to early June, or late July to August, plants had the least production. Total biomass was greatest in control and the early May defoliation; it was statistically similar among plants that had been defoliated. Production of the current year was positively correlated $(r=0.89, P \leq 0.05)$ with regrowth biomass in 1992.

\section{Management Implications}

Cover, frequency, density, and production of winterfat were substantially greater than previously reported in the Northern Mixed Prairie of Canada (Clarke et al. 1943, Clarke and Tisdale 1936, 1945, Coupland 1950, Smoliak 1965). It is possible that these earlier studies underestimated the importance of this shrub on Northern Mixed Prairie because it declines substantially under grazing, and study sites might not have been fully recovered from previous grazing.

The decline of winterfat under grazing can be attributed to its pattern of growth in relation to grazing during the growing season. As evidenced by production of current year, the growth period for winterfat extends from May into August with standing crop peaking in late July or August. Some growth may occur earlier in the season than reported here, but our sampling did not include this period. Photosynthetic carbon fixation for winterfat is greatest from April through July, being limited by moisture deficits in late summer (Caldwell et al. 1977).

Table 3. Total biomass averaged across sampling dates for winterfat defoliated in 1990 and sampled in 1991.

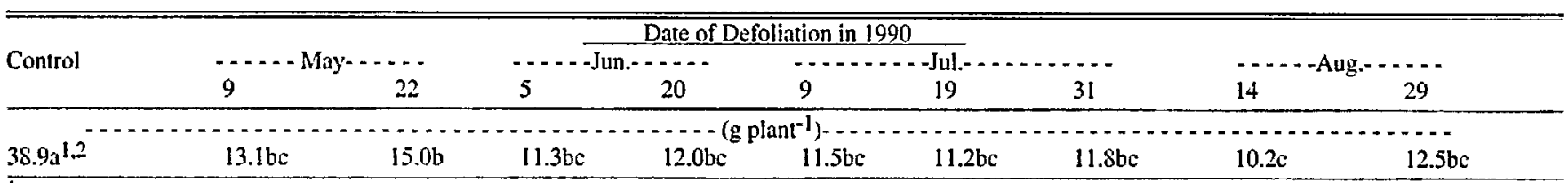

Means tollowed by the same letter are not ignuticunily different $(P \geq 0.05)$.

SStandard error is 1.7 . 


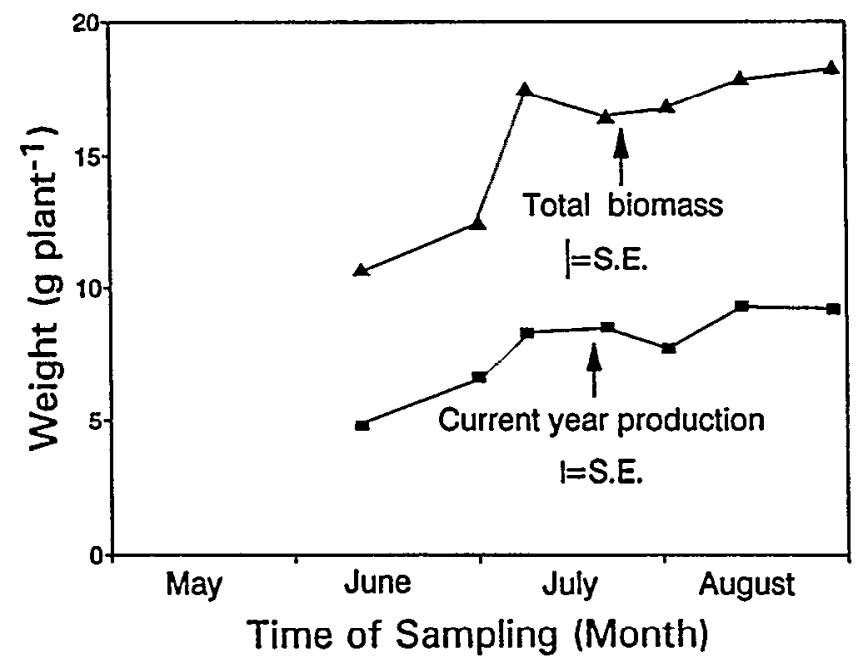

Fig. 4. Total biomass and current year production averaged across control and defoliation treatments for winterfat defoliated in 1992 and sampled in 1993. S.E. is standard error for the means.

Because winterfat grows throughout the summer, and substantial amounts of new growth are produced following defoliation, it is vulnerable to having regrowth grazed if livestock are not removed after the initial defoliation. The possible exception to this is in August or later when regrowth is minimal following defoliation. Late season use will minimize opportunities for growth of new biomass and its removal if the grazing period is protracted. In contrast, regrowth will likely be consumed under continuous grazing, in grazing systems that include more than 1 grazing period during the growing season, or in those with prolonged periods of grazing.

The length of time winterfat had to regrow following defoliation impacted productivity the next year. More than 1 growing season may be required to regain productivity if winterfat is grazed during June, July, or August. Plants that were defoliated in late July or August tended to produce the least biomass the following year, while those defoliated earlier produced more. Cook and Child (1971) found defoliation in late spring was more harmful to winterfat than early spring defoliation. It is possible that plants were weakened by defoliation in late summer because carbohydrates reserves may have been low as noted by Coyne and Cook (1970). Longer periods of growth that were associated with earlier defoliation may also expose plants to favorable environmental conditions for activation of meristems, production of new leaves. and high rates of photosynthesis (Caldwell et al. 1981, Richards and Caldwell 1985). In contrast, because there was essentially no regrowth in the year of defoliation for plants defoliated in late July or August, the lack of active meristems (Wandera et al. 1992) may have limited production the following year. We observed that growth originated primarily from crowns on plants that were defoliated late the previous year, while those in the early defoliation treatments produced most new growth from shoots produced the year before.

Winterfat represents a potential late season forage in the Northern Mixed Prairie. In fall and winter it's nutritive value is high relative to most grasses (Clarke and Tisdale 1945, Smoliak and Bezeau 1967). To realize the benefits of winterfat, however, not only must productivity and forage quality be taken into account, but allowances must also be made for its regeneration. Winterfat flowers in June, seeds develop through the summer and

Table 4. Current year production and total biomass averaged across sampling dates for winterfat defoliated in 1991 and sampled in 1992.

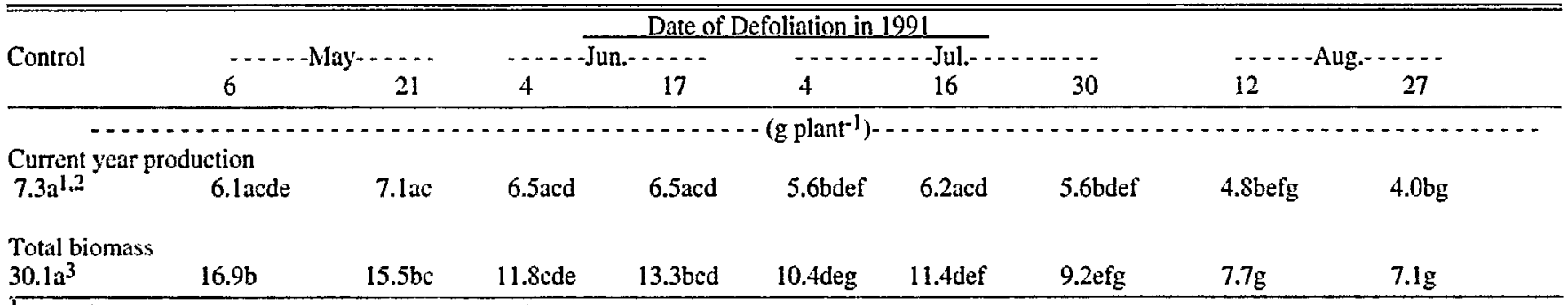

Mean $>$ followed by the same letter are not signticantly different $(P \geq 0.05)$.

2 Standard error for current year production is 0.4 .

3 Standard error for total biomas is 1.3 .

Table 5. Current year production and total biomass averaged across sampling dates for winterfat defoliated in 1992 and sampled in 1993.

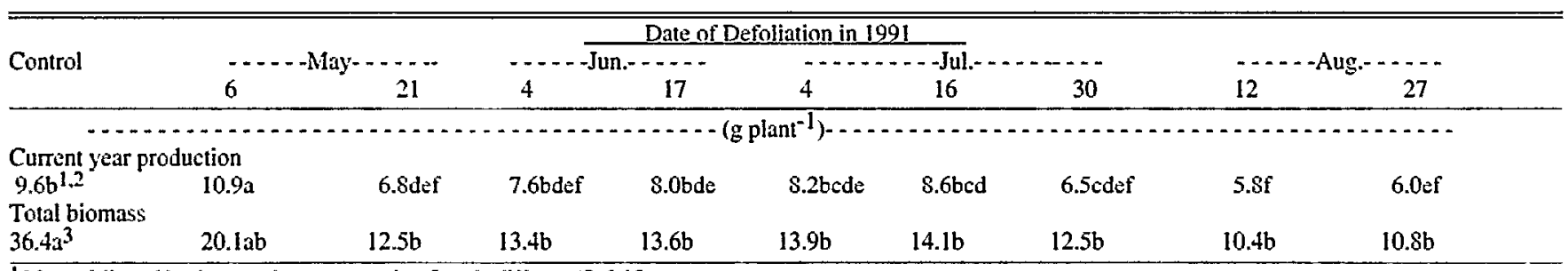

${ }_{1}$ Means followed by the same letter are not signticantly different $(P \geq 0.05)$.

2 Standard error tor current year production is 08

3 Standard error for total biomass is 1.8 . 
most are shed in mid-September through October (J.T. Romo pers. obs). Therefore to maintain or increase populations of winterfat, grazing must be deferred periodically until at least late October to allow seeds to be produced and dispersed. The requirements for seedling recruitment have yet to be determined. Although the impacts of grazing winterfat while it is dormant in the Northern Great Plains are not known, use during this period is least harmful to this shrub elsewhere (Cook and Child 1971). Deferring use will also enable winterfat to reach peak standing crop.

\section{Literature Cited}

Abouguendia, Z. M. 1990. A practical guide to planning for management and improvement of Saskatchewan rangeland-Range plan development. New Pastures and Grazing Tech. Proj. Sask. Rural Develop. Regina, Saskatchewan.

Bilbrough, C.J., and J.H. Richards. 1993. Growth of sagebrush and bitterbrush following simulated winter browsing: Mechanisms of tolerance. Ecol. $74481-492$.

Caldwell, M.M. 1984. Plant requirements for prudent grazing. p. 117152. In: Developing strategies for rangeland management. Nat.Res. Counc. Nat. Acad. of Sci. Westview Press, Boulder, Colo.

Caldwell, M.M., R.S. White, R.T. Moore, and L.B. Camp. 1977. Carbon balance, productivity, and water use of Cold-Winter Desert shrub communities dominated by $\mathrm{C}_{3}$ and $\mathrm{C}_{4}$ species. Oecologia 29:275-300.

Caldwell, M.M., J.H. Richards, D.A. Johnson, R.S. Nowak, and R.S. Dzurec. 1981. Coping with herbivory: Photosynthetic capacity and resource allocation in two semiarid Agropyron bunchgrasses. Oecologia 50: 14-24.

Clarke, S.E., E.W. Tisdale, and N.A. Skoglund. 1943. The effects of climate and grazing practices on short-grass prairie vegetation in southern Alberta and southwestern Saskatchewan. Dominion of Canada, Dep. of Agr. Tech. Bull. No. 46. Ottawa, Ontario.

Clarke, S.E., and E.W. Tisdale. 1936. Runge pasture studies in southern Alberta and Saskatchewan. Herb. Rev. 4:53-64.

Clarke, S.E., and E.W. Tisdale. 1945. The chemical composition of native forage plants of southern Alberta and Saskatchewan in relation to grazing practices. Dominion of Canada, Dep. of Agr.. Tech. Bull. No. 54. Ottawa. Ontario.

Cook, C.W., and R.D. Child. 1971. Recovery of desert plants in various states of vigor. J. Range Manage. 24:339-343.

Coupland, R.T. 1950. Ecology of Mixed Prairie in Canada. Ecol. Monogr. 20:271-315.

Coupland, R.T. 1961. A reconsideration of grassland classification in the Northern Great Plains of North America. J. Ecol. 49:135-167.

Coupland, R.T., J.R. Willard, and E.A. Ripley. 1974. Summary of activities, 1967-1974. Matador Project Tech. Rep. No. 69. Univ. of Saskatchewan. Saskatoon, Saskatchewan.

Coyne, P.I., and C.W. Cook. 1970. Sxasonal carbohydrate reserve cycles in eight desert range species. J. Range Manage. 23:438-444.

Fernandez, O.A., and M.M. Caldwell. 1975. Phenology and dynamics of root growth of three cool semi-desert shrubs under field conditions. J. Ecol. 63: 703-714.

Kinsinger, F.E., R.E. Eckert, and P.O. Currie. 1960. A comparison of the line-interception, variable-plot and loop methods as used to measure shrub-crown cover. J. Range Manage. 13:17-21.

Moore, R.T., White, R.S., and M.M. Caldwell. 1972. Transpiration of Atriplex confertifolia and Eurotia lanata in relation to soil, plant, and atmospheric stresses. Can. J. Bot. 50:2411-2418.

Petersen, R.G. 1985. Design and analy'ses of experiments. Marcel Dekker, New York. N.Y

Richards, J.H., and M.M. Caldwell. 1985. Soluble carbohydrates, concurrent photosynthesis and efficiency in regrowth following defoliation: A field study with Agropyron species. J. Appl. Ecol. 22:907-920.
Smoliak, S. 1965. A comparison of ungrazed and lightly grazed StipaBouteloua prairie in southeastern Alberta. Can. J. Plant Sci. 45:270275.

Smoliak, S., and L.M. Bezeau. 1967. Chemical composition and in vitro digestibility of range forage plants of the Stipa-Bouteloua prairie. Can. J. Plant Sci. 47:161-167.

Wandera, J.L., Richards, J.H., and R.J. Mueller. 1992. The relationships between relative growth rate, meristematic potential and compensatory growth of semiarid-land shrubs. Oecologia 90: 391-398.

Zhang, J., and J.T. Romo. 1994. Defoliation of a northern wheatgrass community: Above- and belowground phytomass productivity. $J$. Range Manage. 47:279-284. 